\title{
Jakość życia chorych na chorobę Alzheimera
}

\author{
The life quality of the people suffering from Alzheimer's disease
}

\author{
Dorota Kozak-Putowska, Joanna Iłżecka
}

Samodzielna Pracownia Rehabilitacji Neurologicznej, Katedra Rehabilitacji, Fizjoterapii i Balneoterapii Uniwersytetu Medycznego w Lublinie

AUTOR DO KORESPONDENCJI:

Joanna lłżecka

Szerokie 6B, 20-050 Lublin

tel./fax: +48817502434

e-mail: ilzecka@onet.pl

\section{STRESZCZENIE JuKOŚĆĊYCIA CHORYCH NA CHOROBEE ALZHEIMERA}

Wprowadzenie. Chorobę Alzheimera charakteryzuje postępujący proces otępienny. Nie ma leku zatrzymującego ten proces, chory nie rozpoznaje wczesnych objawów choroby. Staje się stopniowo niesamodzielny w czynnościach dnia codziennego, nie jest w stanie zadbać o siebie, traci kontakt z otoczeniem i rzeczywistością, zaczyna odczuwać niepokojące objawy, izoluje społecznie. Wszystkie te aspekty wpływają na obniżenie i pogorszenie jakości życia chorego z chorobą Alzheimera.

Cel pracy. Celem pracy była analiza dostępnych publikacji dotyczących jakości życia pacjentów z chorobą Alzheimera.

Słowa kluczowe: choroba Alzheimera, jakość życia, neurozwyrodnienie

ABSTRACT WHE LIFE QUALIIY OF THE PEOPLE SUFFERING FROM ALZHEIMER'S DISEASE

Introduction. Alzheimer's disease is characterized by progressive dementia process. There's no medicine available to hinder that process. In case, the ill individual is unable to diagnose early symptoms of the disease, they call a doctor in the moment when a neurotic atrophy is irreversible. The patient is gradually losing self-reliance in everyday activities, the ability to take care of themselves, loses touch with the reality and surrounding world, begins to experience distressing symptoms and becomes isolated from the society. All these factors affect the life quality of an individual suffering from Alzheimer's disease.

Aim. The present article provides an analysis of literature on the quality of life in people suffering from Alzheimer's disease.

Key words: Alzheimer's disease, quality of life, neuronal degeneration

\section{WPROWADZENIE}

Choroba Alzheimera jest neurodegeneracyjną, przewlekłą i postępującą chorobą otępienną, dotykającą osoby powyżej 60 roku życia. Literatura podaje, że w Polsce obecnie jest 200-250 tysięcy chorych na chorobę Alzheimera $[1,2,3]$. Jej przyczyną jest uwarunkowanie genetyczne oraz prawdopodobnie czynniki środowiskowe. Istotą choroby są dwie charakterystyczne zmiany zachodzące $w$ mózgu: odkładanie się białka tau i $\beta$-amyloidu w ścianach naczyń krwionośnych i wokół neuronów oraz uszkodzenie w obrębie neuronów. Prowadzi to do śmierci neuronów, rozwoju procesu zapalnego i w konsekwencji, stopniowego zaniku mózgu. Zmiany zwyrodnieniowe komórek nerwowych wpływają na obniżenie produkcji neuroprzekaźników, głównie acetylocholiny $[1,3]$. Powyższe zmiany doprowadzają do postępującego otępienia.

Oprócz podłoża genetycznego czynnikami ryzyka może być wiek, płeć (częściej chorują kobiety), obecność apolipoproteiny E4, przebyte urazy głowy (choć są kontrowersje w literaturze na temat tego czynnika), choroby tarczycy, występowanie depresji w wywiadzie, palenie papierosów, infekcje wirusowe (HSV1), nadciśnienie tętnicze, hiperlipidemia, niska aktywność fizyczna, niski poziom wykształcenia, samotność, izolowanie się, brak kontaktów towarzyskich oraz współistnienie zaburzeń naczyń mózgowych $[3,4]$. Udowodniono także wpływ ekspozycji zawodowej na pestycydy i inne toksyczne związki na ryzyko rozwoju choroby Alzheimera. Występują sporadyczne przypadki pojawienia się choroby Alzheimera u osób nie podających w wywiadzie chorób otępiennych ani mutacji genetycznych [5].

Choroby Alzheimera nie można wyleczyć, nie można też jej zapobiec. Jest to choroba przewlekła, która kończy się śmiercią. Początek choroby trudno rozpoznać, gdyż pacjent nie czując objawów choroby, nie szuka pomocy lekarza. W momencie zdiagnozowania choroby $60 \%$ neuronów bezpowrotnie już zanikło, leczenie przyczynowe jest wtedy niemożliwe. Jeśli udałoby się opracować metody rozpoznania choroby od początku trwania procesu degeneracyjnego, przed wystąpieniem objawów, leki znacznie opóźniłyby rozwój i przebieg choroby. Nie ma jednak leku przerywającego samą degenerację neuronów. Dla okresu choroby, gdy jeszcze nie ma otępienia, określono definicję łagodnych zaburzeń poznawczych MCI (ang. mild cognitive impairment) [6,7].

Po zdiagnozowaniu choroby Alzheimera pacjent powinien być pod stałą opieką lekarza neurologa i psychiatry. Mogą rozwinąć się również inne choroby czy dolegliwości, których chory sam nie zauważy, dlatego 
też ważne są częste kontrole u lekarza ogólnego. Przebieg choroby jest różny u każdego pacjenta, objawy pojawiają się $\mathrm{w}$ różnej kolejności oraz różny jest czas trwania kolejnych etapów [1].

\section{JAKOŚĆ ŻYCIA CHOREGO Z CHOROBĄ ALZHEIMERA}

Jakość życia (QL - quality of life) nie jest łatwo określić, ze względu na wieloznaczność tej definicji. Pierwsze, stworzone pojęcie, oznaczało dobre życie materialne (posiadanie własnego domu, samochodu), później była to już ocena obecnego położenia życiowego człowieka w sensie „być” (nie „mieć”). Jest to jednak ocena subiektywna jednostki i podlega ciągłym zmianom różnych czynników zewnętrznych i wewnętrznych $[8,9]$.

Według WHO jakość życia to „sposób postrzegania przez jednostkę swojej pozycji w życiu, w kontekście kultury $i$ systemu wartości, $w$ których egzystuje, $i$ w powiązaniu z własnymi celami, oczekiwaniami, standardami i obawami” [10].

Początkowo medycyna głównie koncentrowała się na wydłużaniu czasu życia chorych, co było miernikiem skuteczności prowadzonego leczenia. Dopiero później zaczęto brać pod uwagę uczynienie uratowanego życia godnym, a nawet szczęśliwym. Definicja jakości życia uwzględniająca problemy zdrowotne określana jest jako HRQL - Heath Related Quality of Life. Zgodnie z nią jakość życia jest funkcjonalnym skutkiem choroby i zastosowanego leczenia w ocenie samego pacjenta [9].

Dziedziny jakości życia uwarunkowanej stanem zdrowia to: stan fizyczny (w którym ocenia się sprawność podstawowych funkcji fizjologicznych, zdolność zaspokajania swoich potrzeb, zdolność wykonywania czynności samoobsługowych dnia codziennego, wykonywanie prac umysłowych i fizycznych), stan psychiczny (w którym ocenia się stopień zaakceptowania choroby, występowanie negatywnych i pozytywnych emocji i uczuć (np. złość, przygnębienie, smutek, radość, zadowolenie), sfera społeczna (w której ocenia się motywację i chęć do angażowania się w aktywność społeczną, zdolność pełnienia ról społecznych, utrzymywanie i nawiązywanie kontaktów towarzyskich) oraz sfera doznań somatycznych (która pokazuje wpływ objawów chorobowych na jakość życia pacjenta) $[8,9]$.

Oceniając i analizując powyższe dziedziny można zbadać jakość życia pacjentów w porównaniu z populacją ludzi zdrowych, zaobserwować różnicę efektu działania nowo zastosowanego leku na jakość życia w porównaniu z lekiem stosowanym wcześniej, określić skutki leczenia na stan psychiczny oraz zbadać stopień poprawy jakości życia po zastosowanym rodzaju terapii [9].

Postępujący, wyniszczający charakter choroby Alzheimera sprawia, że w znacznym stopniu, choroba ogranicza życie chorych we wszystkich sferach jego życia i wpływa na jakość życia. Pojawiające się stopniowo objawy zaburzają codzienne życie i oddziałują na cała rodzinę opiekującą się chorym.
Zaburzenia neurokognitywne, w tym głównie zaburzenia pamięci, objawy neuropsychiatryczne, otępienie, utrata umiejętności wykonywania czynności dnia codziennego prowadzą do niesamodzielności, zależności od innych osób i niskiej jakości życia $[11,12]$. Hoc i wsp. [13] oraz Barca i wsp. [14] wykazali w swoich badaniach, że najważniejszym czynnikiem znacząco obniżającym jakość życia u osób z chorobą Alzheimera jest niemożność samodzielnego codziennego funkcjonowania oraz depresja. Inne badania, przeprowadzone przez Shin i wsp. [15] pokazują, że na niską jakość życia wpływają przede wszystkim zaburzenia zachowania.

W badaniu jakości życia osób z chorobą Alzheimera bierze się pod uwagę następujące aspekty: funkcjonowanie poznawcze, zdolność wykonywania podstawowych czynności dnia codziennego ( $A D L$ - activities of daily living), zachowania społeczne oraz stan psychiczny. Bardzo istotna jest ocena funkcjonalna, która umożliwia ocenę stopnia niepełnosprawności, co z kolei ułatwia oszacowanie potrzeb dotyczących opieki nad chorym, zaplanowanie wsparcia społecznego, ocenienie obciążenia opiekunów oraz wyników rehabilitacji $[2,16]$.

Skale oceny jakości życia osób z chorobą Alzheimera dzieli się na uniwersalne (mogą być użyte do badania jakości życia u osób z różnymi chorobami) oraz specyficzne (dotyczące tylko choroby Alzheimera lub innej choroby neurodegeneracyjnej). Skale uniwersalne to np. kwestionariusz oceny jakości życia SF-36 czy The World Health Organization Quality of Life (WHOQOL) - BREFF. Skale specyficzne dla choroby Alzheimera to m.in.: Quality of Life Assessment Scale on Alzheiemr's Disease (Qol$A D)$, The Cornell Brown Scale for Quality of Life in Dementia (CBS), Alzheimer's Disease - Related Quality of Life $(A D R Q L)$. Istnieją również skale oceniające jakość życia rodziny czy opiekunów osób z chorobą Alzheimera [16].

Choroba Alzheimera trwa latami. W tym czasie w organizmie i świadomości chorego zachodzi szereg niekorzystnych zmian, będących efektem trwającego procesu degeneracyjnego. $\mathrm{W}$ miarę wczesne zastosowanie odpowiednich leków hamuje i poprawia stan chorego, ale nie zatrzymuje procesu chorobowego. $\mathrm{Z}$ upływem czasu pojawiają się nowe objawy i dolegliwości oraz skutki uboczne stosowanego leczenia, co wymaga interwencji lekarskiej czy pobytów w szpitalu. Wszystko to jest uciążliwe dla chorego i jest źródłem stresu. Choroba Alzheimera staje się przeszkodą w cieszeniu się życiem, przekreśla cele i plany.

Definicja jakości życia, którą posługują się teoretycy w celu opisania statusu osoby starszej może być dwuznacznie rozumiana. Postępująca niedołężność jest trudna, upokarzająca i ogranicza życie chorego we wszystkich wymiarach. Nie zawsze jednak jakość życia człowieka $\mathrm{z}$ otępieniem jest niska. Należy również brać pod uwagę fakt, że jednostki takie mają chwile radości, szczególnie w początkowych etapach choroby, jak też nie można ich wykluczać w późniejszym okresie. Hołub posłużył się w swojej pracy myślą, że „my stojący na 
zewnątrz musimy być ostrożni $\mathrm{z}$ wydawaniem sądu na temat jakości życia tych, którzy cierpią na demencję" [17].

Jakość życia chorego z chorobą Alzheimera zależy od fazy choroby. W łagodnej fazie choroby, kiedy pacjent jest jeszcze w stanie zaspokajać swoje potrzeby, a wydolność funkcjonalna nie jest znacznie zaburzona, wystarczy mobilizować chorego do dbania o higienę, ubieranie się i samodzielne zaspokajanie podstawowych potrzeb życiowych. Natomiast w zaawansowanym stadium, kiedy chory nie jest w stanie samodzielnie funkcjonować, całość opieki przejmuje otoczenie. Zmienia się życie nie tylko osoby chorej ale także jej opiekuna i całej rodziny pozostającej w bliskim kontakcie z chorym, problemy występujące u chorych zaczynają narastać, co doprowadza do obniżenia jakości życia [17].

Charakter opieki i relacje z chorym są najważniejszym warunkiem zachowania jakości życia chorego na chorobę Alzheimera na odpowiednim poziomie. Największym błędem jest odwrócenie się od chorego, opuszczenie go, skazanie na samotne cierpienie. W takiej sytuacji na pewno jakość życia chorego ulegnie drastycznemu pogorszeniu. Chory czuje spokój i ma poczucie bezpieczeństwa jeśli ciągle ma w polu widzenie swojego opiekuna. Jest on najważniejszą osobą. Zaspokaja on wszystkie potrzeby chorego, wspiera psychicznie, karmi go, dba by nie zrobił sobie krzywdy nieświadomym postępowaniem, czuwa przy nim przez wiele lat. Schorowany człowiek, nawet $z$ zaburzeniami funkcji poznawczych jest nadal osobą w pełnym tego słowa znaczeniu i choroba nie umniejsza jego wartości. Należy unikać porównywania osoby chorej do stanu i jego osobowości sprzed choroby, takie porównania są przykre zarówno dla osoby chorej jak i rodziny. Należy ich postrzegać takimi, jakimi są w obecnym czasie, okazać akceptację i zrozumienie [11].

$\mathrm{Na}$ jakość życia chorego ma wpływ przede wszystkim otoczenie w którym przebywa, stosunki i relacje $\mathrm{z}$ rodziną i bliskimi, warunki socjalno-bytowe i finansowe oraz rodzaj zastosowanego leczenia. Aby aktywizować chorego, polepszyć jego jakość życia, należy mu wypełnić czas. Mimo postępu choroby mogą oni przez długi czas brać udział w zajęciach, które sprawiają im przyjemność, a nawet szczęście. Również zmiana otoczenia ma pozytywne oddziaływanie na samopoczucie chorego. Nie można jednak zapomnieć, że pacjent z chorobą Alzheimera najlepiej czuje się w swoim otoczeniu, wśród bliskich osób i rzeczy, a obce środowisko wzbudza lęk i złe odczucia [18].

Warto ćwiczyć pamięć chorych poprzez rozwiązywanie krzyżówek, zadawanie krótkich wierszy do nauki. Dobrą formą spędzania czasu jest czytanie, ale potrafią to osoby tylko w pierwszej fazie choroby, później nie mogą oni skoncentrować swojej uwagi i nie rozumieją tego co czytają. Wszystkie te zajęcia powinny odbywać się w towarzystwie osoby opiekującej się, nie mogą być narzucane, męczace, powinny być dostosowane do jego obecnego stanu zdrowia i możliwości. Sposobem uprzyjemnienia czasu jest rozmowa. Poprzez nią chory czuje obecność drugiego człowieka, zainteresowanie i poświęcanie mu uwagi. Takie organizowanie dnia uprzyjemnia życie chorego i daje motywacje do zmagania się z chorobą. Moore, Delaney, Dixon badając podopiecznych domów opieki społecznej cierpiących na chorobę Alzheimera, zauważyli, że aktywne zajęcia na dworze oraz układanie $z$ innymi puzzli sprawia im największą radość i umila codzienny czas. Udowodniono, że ćwiczenia fizyczne wpływają na nastrój i humor chorego, wywołują pozytywne emocje, a przecież to właśnie one gwarantują jakość życia i dobre samopoczucie fizyczne i psychiczne. W badaniach innych autorów dowiedziono istnienie zależności między aktywnością fizyczną u chorych na chorobę Alzheimera a opóźnieniem wystąpienia upośledzenia funkcji poznawczych czy też mniejszego ryzyka wystąpienia lub wyeliminowania depresji $[19,20,21]$.

Omawiając temat jakości życia pacjentów z chorobą Alzheimera nie sposób pominąć jakości życia opiekunów tych osób. Sprawowanie długotrwałej opieki nad tymi osobami, szczególnie w zaawansowanym etapie choroby stanowi duże obciążenie psychiczne, fizyczne, emocjonalne, społeczne oraz finansowe [22]. Życie domowe podporządkowane jest chorobie, konieczne jest duże zaangażowanie, cierpliwość, wyrozumiałość ze strony opiekuna, co powoduje jego zmęczenie oraz może wywoływać sytuacje stresowe. Obecnie duży nacisk kładziony jest na tworzenie programów wsparcia dla opiekunów oraz rozwój stowarzyszeń mających na celu edukację i wsparcie chorych i ich rodzin [23].

\section{PODSUMOWANIE}

Pacjent z chorobą Alzheimera traci zdolność do samodzielnego życia, staje się zależny od innych, nie jest w stanie normalnie funkcjonować w społeczeństwie. Pogorszeniu ulega jakość życia zarówno chorych, jak i ich opiekunów. Aby właściwie zajmować się chorym na chorobę Alzheimera i stworzyć mu warunki w których nie będzie czuł się źle, co wpłynie na jego jakość życia, trzeba umieć postępować z taką osobą. Nie powinno okazywać się mu zniecierpliwienia. Należy cały czas kierować się myślą, że wszystkie jego zachowania i postępowanie wynikają z choroby. Uśmiech, życzliwość, łagodzenie objawów agresji chorego to najważniejsze zasady w opiece. Jeżeli jest to możliwe nie należy wyręczać chorego we wszystkich czynnościach, wykonywanie drobnych obowiązków pozwoli mu na zachowanie poczucia kontroli i odpowiedzialności za siebie, zwiększy jego poczucie wartości i samoocenę, sprawi, że poczuje się pomocny i potrzebny. Ważne jest aby czuł się akceptowany i szanowany jako człowiek, To najważniejszy wykładnik jakości życia $[9,13,19]$.

Badanie jakości życia chorych na chorobą Alzheimera pozwala na świadczenie wyspecjalizowanej opieki medycznej, wytyczenie zapotrzebowania na opiekę oraz organizowanie wsparcia i poradnictwa dla pacjentów i ich rodzin [9]. 


\section{PIŚMIENNICTWO}

1. Parnowski T. Choroba Alzheimera. Med. Rodz. 2003; 1: 47-48.

2. Opara J, Brola W. Aktualne metody oceny czynności życia codziennego w chorobie Alzheimera. Rehab. Med. 2011; 15(1): 21-24.

3. Kucharski R, Ziółkowska-Kochan M, Łachut M, Seredyka A. Choroba Alzheimera Informacje podstawowe. 2007; 5: 29-38.

4. Parnowski T. Otępienie w chorobie Alzheimera - problemy diagnostyczne i terapeutyczne. Geriatr. Pol. 2005; 1: 54-59.

5. Patterson Ch, Feightner J.W, Garcia A. i inn. Diagnosis and treatment of dementia" 1. Risk assessment and primary prevention of Alzheimer disease. Can Med Assoc. 2008; 5: 548-556.

6. Barcikowska M. Choroba Alzheimera - leczenie zależne od stadium. Post. Neurol. Prakt. 2004; 4: 279-280.

7. Turkot A. Opieka nad chorym na chorobę Alzheimera. Bioetyczne Zeszyty Pediatrii. 2003-2004; 1: 69-75.

8. de Walden Gałuszko K. Jakość życia w chorobie nowotworowej. Gdańsk: Wydawnictwo Uniwersytetu Gdańskiego; 1999.

9. Zreda-Pikies A, Kurylak A. Jakość życia dzieci chorujących na ostrą białaczkę limfoblastyczną. Family Med. Prim Care Rev. 2007; 9: 293-296.

10. Tobiasz-Adamczyk B. Jakość życia w naukach społecznych i medycynie. Sztuka Leczenia. 199; 2: 33-40.

11. Jarczewska H. Zachorować na zapominanie. Magazyn Pielęg. i Położ. 2007; 11: 17.

12. Bruvik FK, Ulstein ID, Ranhoff AH, Engedal K. The quality of life of people with dementia and their family carers. Dement Geriatr Cogn Disord. 2012; 34: 7-14.
13. Hoc J, Katona C, Orell M, Livingston G. Quality of life in dementi: care recipient and caregiver perceptions of quality of life in dementia: the LARSER-AD study. Int J Geriatr Psychiatry. 2007; 22: 1031-1036.

14. Barca MI, Engedal K, Laks J, Selbek G. Quality of life among elderly patiemts with dementia in institutions. Dement Geriatr Cogn Disord. 2011; 31: 435-442.

15. Shin J-S, Carter M, Masterman D, et al. Neuropsychiatric symptoms and quality of life in Alzheimer disease. Am J Geriatr Psychiatry. 2005; 13: 469-474.

16. Opara JA. Activities of daily living and quality of life in Alzheimer disease. J Med Life. 2012; 5(2): 162-167.

17. Hołub G. Człowiek u schyłku swojego życia - osoba czy "była osoba". Med. Prakt. 2007; 5: 184-187.

18. Białachowska A. Niesprawność funkcjonalna w umiarkowanym otępieniu w przebiegu choroby Alzheimera. Geriatria. 2010; 4: 5-9.

19. Jagas B. Jak wypełnić czas pacjentowi z chorobą Alzheimera? Pielęgniarka i Położna. 1996; $19: 17$.

20. Moore K, Delaney JA, Dixon MR. Using indices of happiness to examine the influence of environmental enhancements for nursing home residents with Alzheimer's disease. J Apllied Behaviour Analysis. 2007; 40: 41-544.

21. Williams ChL, Tappen RT. Effect of exercise on mood in Nursing Home Residents with Alzheimer's Disease. Am J Alzheimers Disease Other Demen. 2007; 22: 389-397.

22. Grabowska-Fudala B, Jaracz K, Smelkowska A, i wsp. Obciążenie osób sprawujących opiekę nad osobami z chorobą Alzheimera. Wyniki wstepne. Nowiny Lek. 2013, 2013, 82(1): 25-30.

23. Basińska MA, Lewandowska PN, Kasprzak A. Wsparcie społeczne a zmęczenie życiem codziennym u opiekunów osób chorych na chorobę Alzheimera. Psychogeriatr. Pol. 2013; 10(2): 49-58.

Praca przyjęta do druku: 12.11 .2015

Praca zaakceptowana do druku: 20.04.2016 